\title{
A Case Study on Factors Influencing Online Apparel Consumption and Satisfaction between China and Ghana
}

\author{
Francisca M. Ocran ${ }^{1}$, Xiaofen $\mathrm{Ji}^{1,2}$ \& Liling Cai ${ }^{1,2}$ \\ ${ }^{1}$ School of International Education, Zhejiang Sci-Tech University, Hangzhou, China \\ ${ }^{2}$ Silk and Fashion Culture Research Center of Zhejiang Province, Hangzhou, China \\ Correspondence: Xiaofen Ji, School of International Education, Zhejiang Sci-Tech University, 5 Second Avenue, \\ Xiasha Higher Education Zone, Hangzhou, China. Tel: 86-571-86-8431-1453. E-mail: xiaofenji@zstu.edu.cn
}

Received: September 22, 2019

Accepted: September 30, 2019

Online Published: November 13, 2019

doi:10.5539/ass.v15n12p38

URL: https://doi.org/10.5539/ass.v15n12p38

\begin{abstract}
The study explores and compares the influence of perceived online shopping benefits namely convenience, pricing, and wider selection towards online satisfaction between China and Ghana. It also seeks to explore the factors that motivate individuals to shop online. Further, the problem(s) faced by both countries in shopping online is examined. Descriptive analysis, correlation, Anova and regression analysis were used in assessing and comparing consumers' online experience. It was found that there is a high prevalent rate $(97.5 \%)$ of online apparel shopping among Chinese and Ghanaian respondents where the prevalent rate of patronizing online apparel was relatively higher among Chinese youth than the Ghanaian. Convenience, internet usage proficiency and easy access to internet were the main factors that facilitates online apparel shopping among the respondents. Level of income makes the difference in rate online apparel patronization between Chinese and the Ghanaian. On the contrary, level of income, Trust, and Privacy and confidentiality of personal information were found as challenges discourages Ghanaians online apparel consumers likewise Chinese consumers.
\end{abstract}

Keywords: online shopping, online satisfaction, online apparel and shopping experience

\section{Introduction}

The Internet is not only a networking media, but also a global means of transaction for consumers. Ways by which information is being transferred, service and trade has become very common in the last decades due to high usage of the internet (Delafrooz, Paim, \& Khatibi, 2010). The rate by which online shopping was enhancing was very low but now it's growing rapidly. Not much research has been conducted with regards to the online consumption behavior of the Ghanaian populace in relation to apparel. Most research conducted focuses on the financial services; specifically online banking.

A process where by a group of people or an individual choose, buy, or make use of a purchase product to satisfy their needs and wants is known as online consumption or purchasing behavior (Solomon, 1995). Information available to Digital Reader (2014) indicates a lot of consumers is becoming online shoppers at a very fast rate; 3 out of 5 Europeans shopped online in 2012. Much research hasn't been done when it comes to investigating online buying attitudes in Ghana. Consumer's preference has become the markets concern because if care is not taken into their preference they might lose all their customers, most consumers purchase online with the help of mobile applications and websites. Consumers get the chance to use multiple channels in purchasing the products they need online (Deneen \& Yu, 2015). According to Toñita, Monsuwé, and Ko de Ruyter (2004), the beauty of the website encourage or motivate consumers to purchase more goods online.

In Ghana, most expensive fabrics like Kente and Adinkra cloth are used during important gathering such as naming ceremonies, traditional marriage and festivals. Much phrase has come into consideration when it comes to the use of Kente and Adinkra cloth. These expensive fabrics are the main fabrics the chiefs use to dress (Patrick, 2005). The institution, National Friday Wear Programmed, were set aside their Western suits and ties and opt for locally designed clothing made from locally manufactured fabrics, are representative of the changing mindset of the Ghanaian with respect to these fabrics (Ghana News Agency, 2004). For this reason, Ghanaians have gradually preferred more of customs made from African fabric. These apparel, most are made by natives, do not have a standard measurement, they are often sewed to suit measurement provided by the consumer. This 
doesn't help consumer to purchase product online.

In online shopping environment, consumer behavior doesn't only signifies the purchasing of apparel online only (Hoffman \& Novak, 1996), apparel sellers face intense competition. Apparel marketers and managers try their possible best to take what their consumers tells them into consideration because if much attention is not given to consumers the business will end up collapsing, effective strategy is taken by markers when it comes to consumers knowledge (Goldsmith \& McGregor, 1999). Attitude towards consumers online shopping has been released (e.g. Citrin et al., 2000), few investigations has been taken into consideration when it comes to purchasing apparel online. This research enhances the reviewing aspect by making a comparison between the China and Ghana.

Several studies have examined online shopping in Europe over decades and revealed that they tend to attract in-home channels mainly on account of the amenity (Bhatnagar, 2007). (Cox and Rich 1964) provided support for this after coming up with their findings. It came to realization that consumers with high income buy apparel without going to the store. Gillett (1970) looked out carefully at the demographic characteristics of the online consumers who are at a higher chance of knowing more about online shopping as compared to consumer shoppers (Bhatnagar, 2007). With these findings, the issue now remains, where lies the majority of Ghanaians who live within the middle and low-income strata in comparison with the Chinese who are more in the upper and middle-income strata in relation to their consumption of apparel online.

\section{Theoretical Background and Hypothesis}

\subsection{Control}

Perceived behavioral control According to (Ajzen, 1991) what a person accepts is what shows in the persons day to day activities (Ajzen, 1991, p. 188). According to Theory of Planned Behavior TPB, perceived control has been linked to the belief of individuals. As such the intentions and actual behavior of the individuals are affected by perceived control, the process whereby a consumer controls his or her shopping or purchasing decision is known as perceived control (Elwalda, Lü, \& Ali, 2016). In the Ghanaian case, consumers are unable to customize apparel online rather have to fall on the already made ones, especially with the "African wear" clothing. Apparels sold on the Ghanaian market and the ones demanded by the populace are largely locally sowed dresses which are made of textiles and popularly known as "African wear". This is unlike the Chinese market where largely the apparels are factory made which follow specific measurement. Even in the case of customization of wears, various features on the websites of these apparel dealers allows for control.

It's very difficult to also satisfy your customers but if a marketer or a retailer does his homework well by trying his possible best to satisfy his customers in other to maintain the relationship, at the end of the day it's going to help the marketer in getting more customers and also relying on the previous customers (Engle et al., 1995). In as much as the Ghanaian brands and retailers have tried to provide varied sizes for online shoppers, however, the problem arises when it comes to the "African wear" apparels. The Ghanaian shopper wants a fitting wear, which is tailored to suit him or her as such most would rather walk to the shop to get them.

For a consumer to be satisfied with the apparel he or she buys online a good body measurement should be taken into consideration, the persons figure should be considered well that the height and weight of the person (Brown \& Rice, 2014). When it comes to females apparel it's very stressful and difficult at times because most times consumers doesn't get what they wanted, it's either the apparel is big in size or its smaller on them. As a marketer if you want to promote your brand garment size should really be explained well (Silverman, 2009). Barbaro (2006), manufactures have come to know that for a consumer to like a brand really relays on the trust the he or she has for the brand, if retailers are truthful to their customer they will always purchase from them because they get satisfied with their apparel. Considering the issues raised, the following hypotheses are formulated.

H1a: Chinese online apparel consumers have greater control than Ghanaian's.

H1b: Consumers' ability to have control positively predicts their online consumption of apparel.

H1c: Consumers' control of the apparel fitting the body moderates the relationship between consumers' motivators and decision to consume.

\subsection{Amenity}

In the proposal by Jiang et al. (2013), five measurements of perceived amenity were pointed out in shopping online; approach, explore, judge and rate, trade and post purchase. For a consumer to get a good online shopping environment customers amenity should be considered because amenity is a key factor in online shopping 
(Clemes, Gan, \& Zhang, 2014) most people try to avoid overcrowding, not to talk of wasting much time and also having access to whatever they want at any point in time of their life. Online shopping is available 24hours every single day, once a customer have access to internet and also have money on his or credit card he or she can purchase items online at point in time. Most foreigners in China tries to avoid embarrassment because you enter a shop and you're being spoken to in Chinese it's sometimes frustrating when someone don't understand you, spending so much time in a queue to just get a retailer to attend to you becomes a problem therefore it's very convenient to shop online. If a consumer will shop online it depends on the attractive or easy access website created (Davari, Iyer, \& Rokonuzzaman, 2016). If your customer gets a good feeling about shopping from your shop online it greats a good impression about you because the customer will surely advertise to her friends to shop from you. Markers should therefore make their website flexible for consumer's (Forsythe \& Shi, 2003).

H2a: Chinese online consumers of apparel have greater amenity than Ghanaian online consumers.

H2b: Consumers' amenity positively predicts their online consumption of apparel.

\subsection{Felicity}

Felicity can be explained as trying to make something satisfying in its own best interest (Venkatesh, 2000, p. 351). Felicity in apparel online shopping could be explained as how consumers get satisfied or enjoy the use of the website to purchase products online. At some peoples leisure time they like to browse online to check the latest goods this is termed as entertainment to some consumers. Due to this consumers have the full time to rely analyze what they want to purchase, they have the whole time to evaluate and make their final decision before purchasing therefore consumers risk are being limited. Researchers have made it known the felicity role in intrinsic motivation to explain information system's adoption (Davis, Bagozzi, \& Warshaw, 1992; Elwalda, Lü, \& Ali, 2016; Rouibah, Lowry, \& Hwang, 2016).

H3a: The Chinese consumer of apparel felicies more than Ghanaian consumers.

H3b: Consumers' felicity positively predicts their online consumption of apparel.

H3c: The difference between Chinese consumer's felicity and Ghanaian consumer's felicity is largely due to the moderating effect of poor internet access.

\subsection{Perceived Risk}

The most important factors that influence consumer purchasing decision making are security control and privacy issues related to transactions in Global Network (Singh \& Sirdeshmukh, 2000).

Fishbein's model, identifies five items for online purchaser which is comes with risk: the intention of the consumer attitude toward online shopping, levels of satisfaction, and the process of purchasing and decision-making (Lilien et al., 1992). Internet security has been shown to be the major concern of most internet surf that surfs as a hindrance to online transactions (Hassan, Kunz, Pearson, \& Mohamed, 2006). This is exactly the situation among the Ghanaian apparel consumer. A lot of risk has been shown when it comes to online shopping (Jacoby \& Kaplan, 1972) and these risk could be how money is being managed, how human mind and feelings are seen, activity, social and physical by Roselius (1971) and protection risk by Ueltschy, Krampf, \& Yannopoulos (2004). However, the risk raises a restricting impact on purchasing apparel from online, it is very relevant for website owners to use a software or have an indicating risk feature if this is done it will reduce the perceived risk (Griffin \& Viehland, 2010).

Generally, it is observed that "risk consumers who are not noticeable are more likely than risk-averse consumers to consummate a buying transaction when faced with buying a product (or service) with uncertain outcomes or possible loss" (Gupta, Su, \& Walter, 2004).

H4a: Chinese online consumers are less at risk compared to Ghanaian online consumers of apparel.

H4b: Risk perception minimize the relationship between consumers' motivators and decision to consume.

\subsection{Thinking Patterns of Consumers: Holistic vs. Analytic}

Analytic and holistic thoughts are two broad categories of individual's cognitive differences (Peng \& Nisbett, 1999; Nisbett, 1998; Nisbett et al., 2001). Holistic thinkers are people who take a very close look at the product and also accepts the inscriptions written on them, they finally accepts the products based on what they see and the inscriptions written whilst the analytic thinkers doesn't really depend on the inscription written on the product they like to read and know more about the product before they purchase them (John, 2004; Norenzayan et al., 2002). Most researches have made it known that both concentrates on the products and its inscriptions but holistic thinkers does it more as compared to analytic thinkers (Ji et al., 2000). The way a consumer thinks or 
access things affects what he or she purchase (Monga \& John, 2007; Ahluwalia, 2008). When it comes to brand description both holistic thinkers and analytic thinkers show the same attitude (Monga \& John, 2010). Holistic thinkers, on the contrary, relay on the description rather than the products (Choi, Nisbett, \& Norenzayan, 1999), when purchasing a product from the brands original shop it's simple for the consumer to trust the shop because they know the products are original (Monga \& John, 2010). Additionally, holistic thinkers are found to illustrate a stronger affection between things ( $\mathrm{Ji}$ et al., 2000). This review assumes the style of thinking; analytic and holistic, would predict consumers felicity, control, and amenity.

\section{Empirical Analysis}

\subsection{Data Collection and Measures}

Questionnaires were the main survey instrument used in the collection of the data. With the exception of the demographic characteristics of the respondents, all other questions were measured using a five-point Likert scale, ranging from "strongly disagree (1)" to "strongly agree (5)." The study provides an analysis of the empirical data collected from the survey carried within the developed country (China) and the developing country (Ghana). A quantitative survey was carried focusing on people within universities. In order to address each of the specific objectives of the study, the analyses have been captured under different headings, background information of the respondents in order to contextualize the study, the prevalence and patterns of online apparel consumption among university, the third section analyses the facilitators or factors that predict online apparel purchases among consumers. The subsequent sections describe consumers' online experience between Ghana and China and barriers to online apparel purchases.

\subsection{Socio Demographic Characteristics}

The study revealed that, the majority (54.5\%) of the respondents were males, aged 20-35 years (55\%), with $(50.0 \%)$ Chinese and Ghanaians appease. Also, majority of the respondents were Graduates (49.4\%), access to internet and use it every day (63.3\%), and mostly use it for online networking (100\%), online shopping $(97.5 \%)$ and e-mailing (71.0\%). All respondents had ever participated in online transaction of apparel before with $(67.5 \%)$ accessed online market platforms not more than a year prior to the study (see Table 1). This implies that the respondents has the characteristics that depicts them as online apparel consumers, thereby, could be confirmed as credible respondents for the study.

\section{Result and Discussion}

\subsection{Amenity Influences Consumer's Online Experience in Apparel Shopping}

The result shows that the overall mean of the items representing amenity is less than 3.0. This means that respondents of both Chinese and Ghanaians do not generally agree that online amenity in terms of access and easy use of online apparel vendor's apps or sites, able to locate information on it and evaluate does not directly influence their shopping experience. This finding validates the hypothesis that Chinese online consumers of apparel does not have greater amenity than Ghanaian online consumers see Table 2

\subsection{Thinking Patterns of Online Consumers Regarding Shopping of Apparel}

Thinking patterns of consumer in terms of trust in online apparel vendors and loved for apparel being holistic or analytic. It was examined whether online consumers believe that online apparel shopping platforms makes them developed required trust to make re-purchase decisions. On a scale of 1 to 5 respondents were asked to describe the extent to which they agree or disagree with the following statements regarding their thinking patterns of shopping of apparel.

The result of the descriptive statistics is presented in Table 2 indicated that the overall mean of thinking pattern of consumers is more than 3.0. This means that respondents do generally agree that their thinking pattern of online apparel shopping influence their shopping experience.

\subsection{Felicity Influences Consumer's Online Experience in Apparel Shopping}

The main purpose of online apparel shopping is to make shopping to consumers convenient, quicker and faster, so that it becomes entertaining or enjoyable and attractive to consumers. From Table 2, it is observed that the mean values of the various items of felicity are greater than 3.5 , which means that respondents strongly agree that felicity of online shopping of apparel significantly influences their purchase behavior, hence, shopping experience.

This finding validates the hypothesis that Consumers' felicities positively predict their online consumption of apparel. Also, the overall mean of the items is greater than 3.5, meaning that respondents agree that online apparel shopping provides some form of convenience and entertainment. 


\subsection{Perceived Control of Online Consumers Regarding Online Apparel Shopping}

It is observed that the mean values of the various items of control are greater than 3.5, which means that respondents agree that they have control in online apparel shopping and thereby significantly influences their purchase behavior and loyalty, hence, shopping experience. This validates the hypothesis that consumers' ability to have control positively predicts their online consumption of apparel.

\subsection{Perceived Risk of Online Consumers Regarding Online Apparel Shopping}

The perception of online consumers towards the credibility of online shopping has been debated in the literature for quite some time now. While others believe that these online shops are credible and provide the needed information about a product and service, others believe that most of them are scam and that they cannot be trusted. This perception was examined empirically in this study and the result is presented in Table 1 . The mean values obtained indicate that respondents are not quite sure whether online luxury shops are credible or not. In other words, respondents neither agree nor disagree that online apparel shopping are credible.

Table 1. Descriptive statistics regarding the factors influencing consumers' experience

\begin{tabular}{|c|c|c|c|}
\hline Variables & $\mathrm{N}$ & Mean & $\begin{array}{c}\text { Std. } \\
\text { Deviation }\end{array}$ \\
\hline I found it difficult to learn how to use online sites/apps to do my shopping activities. & 200 & 3.0161 & 1.30390 \\
\hline I find it easy to locate the information that I need in apparel retailer's website/apps & 200 & 2.6935 & 1.31745 \\
\hline I shop online more frequently because I find the apparel online sites/apps easier to use. & 200 & 2.8266 & 1.29706 \\
\hline Having access to the apparel online market enables me to shop more often than previously. & 200 & 2.7298 & 1.26122 \\
\hline I found it difficult to learn how to use 1 online apparel sites/apps to do my shopping activities. & 200 & 2.2903 & 1.28065 \\
\hline I took a long time to learn to use the apparel online sites/apps to do my shopping activities. & 200 & 2.5081 & 1.28065 \\
\hline Overall Mean & & 2.6774 & \\
\hline $\begin{array}{l}\text { I would use the apparel online sites/apps for my shopping activities in addition to traditional } \\
\text { methods of shopping if I trust a retailer's website. }\end{array}$ & 200 & 3.5605 & 1.16127 \\
\hline $\begin{array}{l}\text { I would use the online apparel sites/apps for my shopping activities because I find online } \\
\text { shopping very useful. }\end{array}$ & 200 & 3.5081 & 1.05704 \\
\hline $\begin{array}{l}\text { I would use online apparel retailer's website for my shopping activities because I find it easy to } \\
\text { use. }\end{array}$ & 200 & 3.5185 & 1.16257 \\
\hline Overall, I like using the apparel online sites/apps for my shopping activities. & 200 & 3.5188 & 1.16286 \\
\hline Overall Mean & & 3.5290 & \\
\hline $\begin{array}{l}\text { Online apparel shops are convenient ( time saving, no queues or crowds, easy to transact and } \\
\text { order) }\end{array}$ & 200 & 3.8615 & 1.13127 \\
\hline Found more varieties and different brands on apparel online shops & 200 & 3.8081 & 1.04704 \\
\hline I found better prices on online apparel shops and easy to compare their prices. & 200 & 3.7185 & 1.14237 \\
\hline Online apparel shops provides me every quality detail information about luxury products. & 200 & 3.8178 & 1.13286 \\
\hline Online apparel shops saves me from impulse / and pressure buying & 200 & 3.8152 & 1.14056 \\
\hline Overall Mean & & 3.5890 & \\
\hline I have adequate income to make online apparel purchase & 200 & 3.8185 & 1.03938 \\
\hline $\begin{array}{l}\text { I have ability to search and select or specified preferred customize (measurement, color, size, } \\
\text { shape) of online apparel. }\end{array}$ & 200 & 3.3306 & 1.08893 \\
\hline I have access and ability to search and test/examine the authenticity of online apparel & 200 & 3.5927 & 1.29756 \\
\hline Overall Mean & & 3.5806 & \\
\hline Transactions of online apparel are not secured with privacy and confidential information. & 200 & 3.3105 & 1.12946 \\
\hline $\begin{array}{l}\text { I feel unsafe providing card/ mobile numbers/ banking details when making payments in online } \\
\text { environments. }\end{array}$ & 200 & 3.1895 & 1.01026 \\
\hline Internet insecurity and poor technical support on websites/apps of apparel shops. & 200 & 3.1895 & 1.01026 \\
\hline Overall Mean & & 3.1518 & \\
\hline
\end{tabular}

Scale (mean) $0-2.5=$ low; $2.51-3.5=$ Average and High=3.51 and above 
From Table 2, it was observed that there are statistical differences $(p<0.05)$ between the thinking pattern, Felicity, perceived risk, control and amenities between Ghana and Chinese apparel consumer s experience. This validates the hypothesis that Chinese online apparel consumers have greater thinking pattern, felicity and perceived control than Ghanaian online apparel consumers. This concluded that the Chinese online apparel consumers have a better online apparel shopping experience than that of the Ghanaian consumers.

Table 2. Results from ANOVA

\begin{tabular}{|c|c|c|c|c|c|c|}
\hline & & Sum of Squares & $\mathrm{df}$ & Mean Square & $F$ & Sig. \\
\hline \multirow{3}{*}{ Amenity } & Ghana & 5.959 & 1 & 5.959 & .651 & .075 \\
\hline & China & 93.952 & 199 & .472 & & \\
\hline & Total & 99.911 & 200 & & & \\
\hline \multirow{3}{*}{ Thinking Pattern } & Ghana & .795 & 1 & .795 & 3.221 & .001 \\
\hline & China & 43.933 & 199 & .220 & & \\
\hline & Total & 44.728 & 200 & & & \\
\hline \multirow{3}{*}{ Felicity } & Ghana & 7.313 & 1 & 7.313 & 14.826 & .000 \\
\hline & China & 87.798 & 199 & .441 & & \\
\hline & Total & 95.111 & 200 & & & \\
\hline \multirow{3}{*}{ Perceived control } & Ghana & 2.356 & 1 & 2.356 & 10.130 & .002 \\
\hline & China & 41.394 & 199 & .208 & & \\
\hline & Total & 43.750 & 200 & & & \\
\hline \multirow{3}{*}{ Perceived risk } & Ghana & .670 & 1 & .670 & 11.26 & .0 .01 \\
\hline & China & 184.058 & 199 & .925 & & \\
\hline & Total & 184.728 & 200 & & & \\
\hline
\end{tabular}

From the correlation analysis displayed in Table 3 , it can be observed that there is a positive relationship between consumer's felicity of online shopping and purchase behavior. $(\beta=0.592, \mathrm{P} \leq 0.05)$. This implies that if consumers perceive online apparel shopping as providing felicity value, they are likely to purchase the apparel. This validates the hypothesis that consumers' felicities positively predict their online consumption of apparel.

Also, it can be observed from the result that there is a significant positive relationship between perceived risk of online shopping and purchase intentions $(\beta=0.621, \mathrm{P} \leq 0.01)$. The implication of this result is that when online consumers perceive that online apparel shops. This validates the hypothesis that risk perception moderates the relationship between consumers' motivators and decision to consume.

Again, it can be observed that there is a positive relationship between consumer's perceived control of online shopping and purchase behavior $(\beta=0.623, \mathrm{P} \leq 0.01)$. This implies that when online consumers perceive to exercise control in online purchasing process, they are more likely to purchase its product/service. This validates the hypothesis consumers' ability to have control positively predicts their online apparel consumption.

Moreover, it can be deduced from the result that the thinking patterns of consumers about online shops is positively related to purchase behavior $(\beta=0.626, \mathrm{P} \leq 0.01)$. This means that when consumers perceive online luxury shops to be ease to use, access, and trustworthy, they more likely to purchase their apparel. This validates the hypothesis that consumers' amenity positively predicts their online apparel consumption.

Table 3. Pearson's moment correlation analysis

\begin{tabular}{|c|c|c|c|c|c|c|}
\hline & & Pbehavior & Amenity & Felicity & P. Risk & TPattern \\
\hline Pbehavior & $\begin{array}{c}\text { Pearson } \\
\text { Correlation } \\
\text { Sig. (2-tailed) }\end{array}$ & 1 & & & & \\
\hline Amenity & $\begin{array}{c}\text { Pearson } \\
\text { Correlation } \\
\text { Sig. (2-tailed) }\end{array}$ & $\begin{array}{l}.034 \\
.593\end{array}$ & 1 & & & \\
\hline Felicity & $\begin{array}{c}\text { Pearson } \\
\text { Correlation } \\
\text { Sig. (2-tailed) }\end{array}$ & $\begin{array}{c}.592^{* *} \\
.000\end{array}$ & $\begin{array}{c}-.054 \\
.394\end{array}$ & 1 & & \\
\hline
\end{tabular}




\begin{tabular}{|c|c|c|c|c|c|c|}
\hline \multirow{3}{*}{ Perceived Risk } & Pearson & $.621^{* *}$ & .095 & $.394^{* *}$ & \multirow{3}{*}{1} & \\
\hline & Correlation & .021 & .093 & $\begin{array}{l}.034 \\
000\end{array}$ & & \\
\hline & Sig. (2-tailed) & & & & & \\
\hline \multirow{2}{*}{ Control } & \multirow{2}{*}{$\begin{array}{c}\text { Pearson } \\
\text { Correlation } \\
\text { Sig. (2-tailed) }\end{array}$} & $.623^{* *}$ & .009 & $.391^{* *}$ & $.482^{* *}$ & \multirow{2}{*}{1} \\
\hline & & .000 & .891 & .000 & .000 & \\
\hline \multirow{4}{*}{ Thinking Patterns } & Pearson & * & & $475^{* *}$ & $524^{* *}$ & $.321^{* *}$ \\
\hline & Correlation & & $.0 \angle 0$ & & .524 & 1 \\
\hline & Sig. (2-tailed) & .000 & .851 & 年. & 年. .000 & .000 \\
\hline & $\mathrm{N}$ & 200 & 200 & 200 & 200 & 200 \\
\hline
\end{tabular}

**. Correlation is significant at the 0.01 level (2-tailed).

From Table 4 , the model used in the analysis is given as $Y=\alpha+\beta 1 X 1+\beta 2 X 2+\beta 3 X 3+\beta 4 X 4+\beta 5 X 5+\varepsilon$,

Where $\mathrm{Y}$; is the dependent variable and $\mathrm{X}_{1}, \mathrm{X}_{2}, \mathrm{X}_{3} \mathrm{X}_{4}$ and $\mathrm{X}_{5}$ are the independent variables. The description of the variables is as follows

$\mathrm{Y}=$ Ghana and China X1= Amenity X2 = Felicity X3 = Control X4 = Perceived Risk and

$\mathrm{X} 5=$ Thinking Patterns, and $\beta \mathrm{i}$ are the coefficient of the variables, $\alpha=$ the intercept of the regression model. $\varepsilon=$ Error term

It can be observed from Table 4 that Felicity, control, perceived risk and thinking pattern of consumers about online apparel shops or shopping significantly affect the purchase behavior of consumers, hence, consumer's loyalty and online experience. This is because the p-values associated with these variables are less than 0.01 $(\mathrm{p} \leq .0 .01)$. This result is also confirmed by the correlation analysis which shows a positive relationship between the variables and purchase behavior.

Table 4. Result of regression analysis

\begin{tabular}{|c|c|c|c|c|c|c|}
\hline & \multirow[t]{2}{*}{ Model } & \multicolumn{2}{|c|}{ Unstandardized Coefficients } & \multirow{2}{*}{$\begin{array}{c}\text { Standardized } \\
\text { Coefficients }\end{array}$} & \multirow[t]{2}{*}{$\mathrm{T}$} & \multirow[t]{2}{*}{ Sig.(Pvalues) } \\
\hline & & B & Std. Error & & & \\
\hline \multirow{6}{*}{1} & (Constant) & 0.099 & 0.201 & & 0.494 & 0.622 \\
\hline & Amenity & 0.017 & 0.037 & 0.018 & 0.449 & 0.654 \\
\hline & Felicity & 0.304 & 0.041 & 0.333 & 7.359 & 0.000 \\
\hline & Control & 0.340 & 0.049 & 0.327 & 6.869 & 0.000 \\
\hline & Perceived Risk & 0.341 & 0.048 & 0.335 & 7.084 & 0.000 \\
\hline & Thinking Patterns & 0.342 & 0.049 & 0.337 & 7.08 & 0.000 \\
\hline
\end{tabular}

a. Dependent Variable: Pbehaviour

Table 5 provides a summary of the regression model. The most important value here is the r-square, which shows the variations in the dependent variable that is explained by the independent variables. From Table 5, it is observed that the Rsquare value is 0.609 or $60.3 \%$. This means that $60.3 \%$ of purchase behavior is explained by the Felicity; control, perceived risk and thinking pattern of consumers about online apparel shopping/Vendors.

Table 5. Model summary

\begin{tabular}{ccccc}
\hline Model & $\mathrm{R}$ & R Square & Adjusted R Square & Std. Error of the Estimate \\
\hline 1 & $0.781^{\mathrm{a}}$ & 0.609 & 0.603 & 0.58792 \\
\hline
\end{tabular}

A. Predictors: (Constant), Felicity, Control, Perceived Risk And T Pattern

Also, in Table 6, the F-statistics value of 2.75 indicates that the independent variables jointly and significantly influence the purchase behavior of consumers which directly affects consumers' loyalty, hence, their online experience. This is in tandem with Liu et al. (2008) that Felicity (information quality, web site design, merchandise attributes, transaction capability), Perceived risk (security/privacy, payment, delivery), and customer service are the various factors that influence consumer's satisfaction and thereby strongly predict consumer s online shopping experience. 
Table 6. Predictive power of the model

\begin{tabular}{ccccccc}
\hline & Model & Sum of Squares & df & Mean Square & F & Sig. \\
\hline \multirow{2}{*}{1} & Regression & 131.081 & 4 & 32.770 & 2.752 & $.000^{\mathrm{b}}$ \\
& Residual & 83.994 & 196 & 0.433 & & \\
& Total & 215.075 & 200 & & & \\
\hline
\end{tabular}

Dependent Variable: Pbehavior

Predictors: (Constant), Felicity, Control, Risk And Patterns

\section{Conclusion}

The extent to which the perception of online apparel consumers in terms of Amenity, Thinking pattern, Felicity, control and risk involved affect the purchase behavior or experience of consumers' needs empirical research to understand. Against this background, the study sought to assess consumers' online shopping experience of Ghana and compare with that of China. It was found out that there is high prevalent rate $(97.5 \%)$ of online apparel consumption among the Ghanaian youth and the Chinese youth. However, it was observed that the prevalent rate of patronization online apparel was high among Chinese youth than the Ghanaian youth.

Again, convenience, internet usage proficiency and easy access to internet were identified as the main factors that facilitate online apparel shopping among both Ghanaians and Chinese respondents. However, level of income makes the difference in rate online apparel patronization between Chinese and the Ghanaian youth. On the contrary, level of income, Trust, and Privacy and confidentiality of personal information were found as challenges or factors that discourages majority of Ghanaian online luxury consumers in consuming online apparel, likewise their Chinese counterparts.

Descriptive analysis and regression analysis were conducted to answer the research questions. The findings revealed that respondents generally have a positive perception about online apparel shopping, but was slightly higher among the Chinese than the Ghanaians. For instance, the respondents found online apparel shopping to be felicity, controllable, credible, informative and entertaining. The study further revealed that perception of online apparel consumers of both countries towards online apparel shopping significantly influences their purchase behavior and online shopping experience. The implication of these findings is that online apparel vendors must take steps to design their online apps that will attract and keep customers.

\section{Acknowledgement}

This work was supported by the Nature Science Foundation of Zhejiang Province (Grant NO. LQ18G020008) School Basic Scientific Research Project (Grant NO. 2019Q140).

\section{References}

Ajzen, I. (1991). The theory of planned behavior. Organizational Behavior and Human Decision Processes, 50 , 179-211. https://doi.org/10.1016/0749-5978 (91)90020-T

Armitage, J. C., \& Conner, M. (2001). Efficacy of the theory of planned behavior: A meta analytic review. British Journal of Social Psychology, 40, 471-499. https://doi.org/10.1348/014466601164939

Barbaro, M. (2006). Clothes that fit the woman not the store. New York Times. Retrieved June 12, 2012, from http://www.nytimes.com/2006/03/31/business/31fit.html

Beauchamp, M. B., \& Ponder, N. (2010). Perceptions of retail convenience for in-store and online shoppers. The Marketing Management Journal, 20(1), 49-65. https://doi.org/10.2478/subboec-2018-0008

Bhatnagar, A. (2007). Do determinants of online shopping differ for personal shoppers and professional? EuroMed Journal of Business, 2(1), 87-102. https://doi.org/10.1108/14502190710749974

Brown, P., \& Rice, J. (1998). Ready-to-wear apparel analysis (2nd ed.). Upper Saddle River, N.J: Menill. https://doi.org/10.1007/978-3-642-39173-6_21

Citrin, A. V., Sprott, D. E., Silverman, S. N., \& Stem, D. E. Jr. (2000). Adoption of internet shopping: The role of consumer innovativeness. Industry Management Data System, 100(7), 294-300. https://doi.org/10.1108/02635570010304806

Clemes, M. D., Gan, C., \& Zhang, J. (2014). An empirical analysis of online shopping adoption in Beijing, China. Journal of Retailing and Consumer Services, 21(3), 364-371. https://doi.org/10.1016/j.jretconser.2013.08.003

Colwell, S. R., Aung, M., Kanetkar, V., \& Holden, A. L. (2008). Toward a measure of service convenience: 
Multiple-item scale development and empirical test. Journal of Services Marketing, 22(2), 160-169. https://doi.org/10.1108/08876040810862895

Cox, D. F., \& Rich, S. V. (1964). Perceived risk and consumer decision-making: The case of telephone shopping. Journal of Marketing Research, 1(4), 32-39. https://doi.org/10.1111/j.1470-6431.1978.tb00324.x

Davari, A., Iyer, P., \& Rokonuzzaman, M. (2016). Identifying the determinants of online retail patronage: A perceived-risk perspective. Journal of Retailing and Customer Service, 33, 186-193. https://doi.org/10.1016/j.jretconser.2016.08.009

Davis, F. D. (1989). Perceived usefulness, perceived ease of use, and user acceptance of information technology. MIS Quarterly, 13(3), 319-40. https://doi.org/10.2307/249008

Davis, F. D., Bagozzi, R. P., \& Warshaw, P. R. (1992). Extrinsic and intrinsic motivation to use computers in the workplace. Journal of Applied Social Psychology, 22(14), 1109-1130. https://doi.org/10.1111/j.1559-1816.1992.tb00945.x

Delafrooz, N., Paim, L. H., \& Khatibi, A. (2011). Students' Online Shopping Behavior: An Empirical Study. Journal of American Science, 66(11), 137-147.

Deneen, K., \& Yu, D. (2015). Online Shopping Is Making Many Customers Antagonistic. https://doi.org/10.1080/23311975.2019.1644715

Eagly, A. H., \& Chaiken, S. (1993). The Psychology of Attitudes. Harcourt Brace Jovanovich, Orlando, FL. https://doi.org/10.1002/mar.4220120509

Elwalda, A., Lü, K., \& Ali, M. (2016). Perceived Derived Attributes of Online Customer Reviews. Computers in Human Behavior, 56, 306-319. https://doi.org/10.1016/j.chb.2015.11.051

Engle, J. F., Blackwell, R. D., \& Miniard, P. W. (1995). Consumer Behavior (8th ed.). Orlando: The Dryden Press. https://doi.org/10.4236/ajc.2018.62006

Fishbein, M., \& Ajzen, I. (1975). Belief, Attitude, Intention and Behavior: An Introduction to Theory and Research. Addison-Wesley, Reading. https://doi.org/10.12691/ajap-1-3-6

Forsythe, S. M., \& Shi, B. (2003). Consumer patronage and risk perceptions in Internet shopping. Journal of Business Research, 56(11), 867-875. https://doi.org/10.1016/S0148-2963(01)00273-9

Gärling, T., Gillholm, R., \& Gärling, A. (1998). Reintroducing attitude theory in travel behavior research. Transportation, 25, 129-146. https://doi.org/10.1023/A:1005004311776

Ghana News Agency. (2004). National Friday Wear Programme Launched. Retrieved October 6, 2012, from http://www.modernghana.com/news/66571/1/national-friday-wearprogramme-launched.html

Goldsmith, E., \& McGregor, S. L. (1998). Extending our understanding of quality of living, standard of living and well-being. Journal of Family and Consumer Sciences, 90(2), 2-6. https://doi.org/10.1007/978-3-319-20738-4_1

Griffin, A., \& Viehland, D. (2010). Perceived risk and risk relievers associated with online shopping. Association for Information Systems, ASeL.

Gupta, A., Su, B., \& Walter, Z. (2004). Risk profile and consumer shopping behavior in electronic and traditional channels. Decision Support Systems, 38(3), 347-67. https://doi.org/10.1016/j.dss.2003.08.002

Hassan, A. M., Kunz, M. B., Pearson, A. W., \& Mohamed, F. A. (2006). Conceptualization and measurement of perceived risk in online shopping. Marketing Management Journal, 16(1), 138-147.

Hoffman, D. L., \& Thomas P. N. (1996). Marketing in Hypermedia Computer Mediated Environments: Conceptual Foundations. Journal of Marketing. https://doi.org/10.2307/1251841

Holbrook, M. B. (1994). The nature of customer value: An axiology of services in the consumption experience. Service Quality: New Directions in Theory, 21-27. https://doi.org/10.4135/9781452229102.n2

Jacoby, J., \& Kaplan, L. B. (1972). The Components of Perceived Risk. In Proceedings of the Third Annual Conference, Association for Consumer Research (pp. 382-393). http://aisel.aisnet.org/acis2010/31

Jiang, L., Yang, Z., \& Jun, M. (2013). Measuring consumer perceptions of online shopping convenience. Journal of Service Management, 24(2), 191-214. https://doi.org/10.1108/09564231311323962

Kunateh, M. A. (2013). Ghana's Internet Penetration Inches To $40.7 \%$. https://doi.org/10.1016/j.elerap.2016.07.001 
Li, N., \& Zhang, P. (2002). Consumer Online Shopping Attitudes and Behavior: An Assessment of Research. In Eighth Americas Conference on Information Systems (pp. 508-517). Syracuse University.

Lilien, G. L., Kotler, P., \& Moarlhy, K. S. (1992). Marketing Model? Prentice-Hall, Englcwaod Cliffs, NJ.

Mathwick, C., Malhotra, N. K., \& Rigdon, E. (2002). The effect of dynamic retail experiences on experiential perceptions of value: An Internet and catalog comparison. Journal of Retailing, 78(1), 51-60. https://doi.org/10.1016/S0022-4359(01)00066-5

Monsuwé, T. P., Dellaert, B. G., \& De Ruyter, K. (2004). What drives consumers to shop? International Journal of Service Industry Management, 15(1), 102-121. https://doi.org/10.1108/09564230410523358

Olshin, B. B. (2006). Debating the Authentic: An Outsider's View of West African Culture in Ghana. Journal of Philosophy and Culture, 1(2), 1-20. https://doi.org/10.4314/jpc.v1i2.36449

Patrick, A. (2005). The Indigenous and global cultural significance of the major textile arts of West Africa with a particular focus on the kente cloth of Ghana and the Bogolanfini Mud cloth of Mali. Retrieved October 4, 2012, from http://content.library.ccsu.edu/cdm/singleitem/collection/ccsutheses/id/1192/re c/5

Perugini, M., \& Conner, M. (2000). Predicting and understanding behavioral volitions: The interplay between goals and behaviors. European Journal of Social Psychology, 30, 705-731. https://doi.org/10.1002/1099-0992(200009/10)30:53.0.CO; 2-\#

Roselius, T. (1971). Consumer Rankings of Risk Reduction Methods. Journal of Marketing, 35, 56-61. https://doi.org/10.1177/002224297103500110

Rouibah, K., Lowry, P. B., \& Hwang, Y. (2016). The effects of perceived risks on trust formation and intentions to use online payment systems: New perspectives from an Arab country. Electronic Commerce Research and Applications, 19, 33-43. https://doi.org/10.1016/j.elerap.2016.07.001

Silverman, D. (2009). Body and image: The challenge of plus size. WWD, 197(13), 19.

Singh, J., \& Sirdeshmukh, D. (2000). Agency and trust mechanisms in consumer satisfaction and loyalty judgments. Journal of Academy of Marketing Science, 28(1), 150-167. https://doi.org/10.1177/0092070300281014

Solomon, M. (1995). Consumer Behaviour (3rd ed.). New Jersey: Prentice Hall.

Toñita, P. Y., Monsuwé, B. G., \& Ko de Ruyter, D. (2004). What drives consumers to shop online? A literature review. International Journal of Service Industry Management, 15(1), 102-121. https://doi.org/10.1108/09564230410523358

Ueltschy, L. C., Krampf, R. F., \& Yannopoulos, P. (2004). A cross-national study of perceived consumer risk towards online (Internet) purchasing. Multinational Business Review, 12(2), 59-82. https://doi.org/10.1108/1525383X200400010

Venkatesh, V. (2000). Determinants of perceived ease of use: Integrating control, intrinsic motivation, and emotion into the technology acceptance model Research. Information Systems, 4(4), 342-65.

Verplanken, B., Aarts, H., \& Van Knippenberg, A. (1997). Habit, information acquisition, and the process of making travel mode choices. European Journal of Social Psychology, 27, 539-560. https://doi.org/10.1023/A:1021282523910

\section{Copyrights}

Copyright for this article is retained by the author(s), with first publication rights granted to the journal.

This is an open-access article distributed under the terms and conditions of the Creative Commons Attribution license (http://creativecommons.org/licenses/by/4.0/). 